5 Фармакология спорта / Горчакова Н.А., Гудивок Я.С., Гунина Л.М. [и др.]; под общ. ред. С.А. Олейника, Л.М. Гуниной, Р.Д. Сейфуллы. - К. : Олимп. л-ра, 2010. - 640 с.

\title{
FIGHT AGAINST DOPING AS A HISTORICAL PROBLEM IN SPORT
}

\author{
(c) 2019 Pilipenko Victoria Andreevna \\ Student \\ (C) 2019 Nalimova Marina Nikolaevna \\ Senior lecturer \\ Samara State University of Economics \\ E-mail: vikabergen2000@yandex.ru
}

Keywords: doping, doping control, anti-Doping Code, World anti-doping Agency.

The article is devoted to the study of the problem of anti-doping in sports.

УДК 37.037

Код РИНЦ 77.00 .00

\section{ИННОВАЦИИ В СФЕРЕ ФИЗИЧЕСКОЙ КУЛЬТУРЫ И СПОРТА}

\author{
(C) 2019 Савельева Ольга Викторовна \\ старший преподаватель \\ (С) 2019 Абрамова Вероника Юрьевна \\ студент \\ Самарский государственный экономический университет \\ E-mail: veronka9909@mail.ru
}

Ключевые слова: инновации, инновационная деятельность, инновации в сфере физической культуры и спорта.

В статье рассмотрены направления развития инноваций в сфере физической культуры и спорта, существующие инновационные проекты в области физической культуры и спорта.

Актуальность. Инновации в настоящее время являются ключевым аспектом развития организаций и отраслей. И отрасль физической культуры и спорта не исключение. Использование инновационных подходов способствует ускорению различных процессов, протекающих в повседневности, благодаря чему уменьшается срок достижения различных целей (получение прибыли, увеличение объемов производства товаров и услуг, выход на новые рынки, увеличение доли рынка, повышение квалификации персонала с помощью приобретения новых знаний и квалификаций). 
В современной жизни особую роль занимает инновационная деятельность. Это подтверждается,

- во-первых, активной поддержкой государственными структурами организаций и предприятий, осуществляющих данную деятельность,

- во-вторых, открытием и широким функционированием разнообразных инновационных центров и технопарков,

- в-третьих, созданием инновационных кластеров.

Инновация - это внедрённое новшество, которое способствует возрастанию эффективности и результативности процессов, востребованное в настоящее время рынком.

Проблема инноваций в спорте, на сегодняшний день, окружена особым вниманием ${ }^{1}$. Это обуславливается колоссальными и масштабными изменениями в экономике, политической сфрере и духовной жизни различных стран, которые не могли не затронуть и область спорта. Актуальности развития инноваций в спорте и физической культуре поспособствовала реализация майского Указа Президента Российской Федерации в отношении увеличения количества систематически занимающихся физической культурой и спортом россиян до 55 \% от доли населения страны².

В России численность занимающихся физической культурой и спортом в период с 2000 - 2017 гг. увеличилась на 17,1\% (рис. 1).

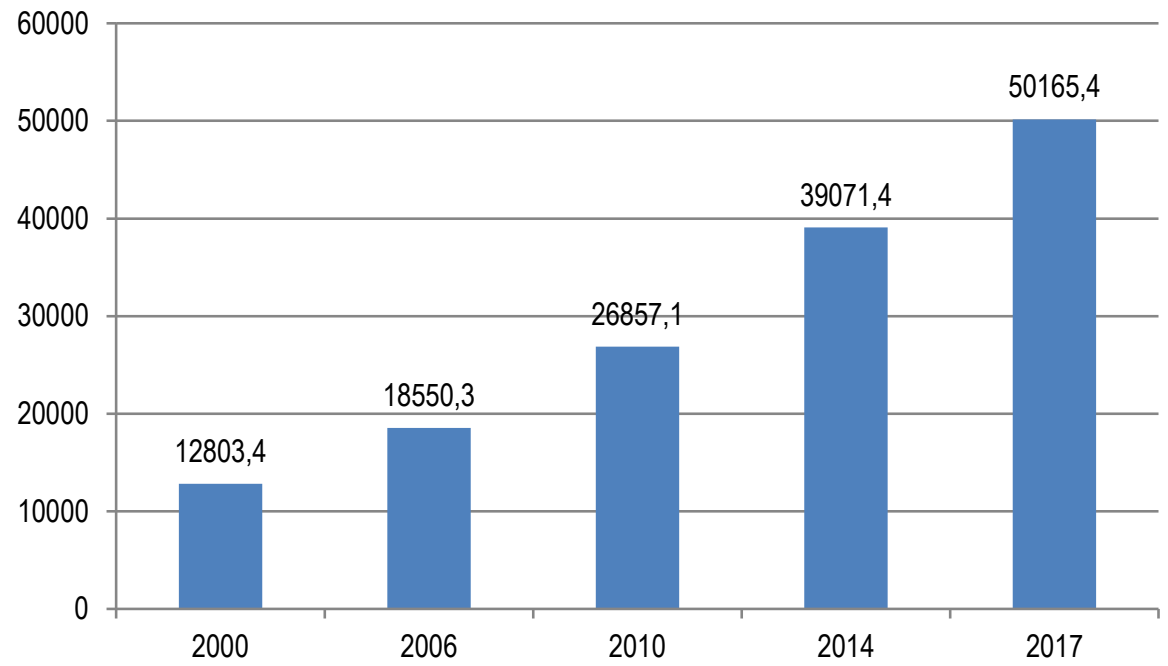

Рис. 1. Численность людей, занимающихся спортом и физической культурой в РФ в 2010-2017³

Рост численности людей, занимающихся физкультурой и спортом, обуславливается:

- увеличением обеспеченности работниками физкультурной направленности;

- увеличением количества спортивных сооружений;

- увеличением финансовых средств, направленных на развитие данной отрасли. 
При этом, не смотря на весомые достижения в сфере физической культуры и спорта, в период с 2000-2017гг. эффрективность физкультурно-спортивной деятельности ухудшилась, а именно уменьшились такие показатели, как: результативность подготовки спортсменов и мастеров спорта, использование спортивных сооружений ${ }^{4}$

Таким образом, данная ситуация, сложившаяся в отрасли спорта и физической культуры, а именно: увеличение количественных показателей и ухудшение качественных показателей, позволяет сделать вывод, что с одной стороны, имеются огромные резервы для роста качественных показателей, а с другой стороны, необходимо использование инновационных подходов в данной сфере.

В области физической культуры и спорте инновации - это, прежде всего, применение принципа междисциплинарности, которые реализуются по нескольким направлениям (рис. 2).

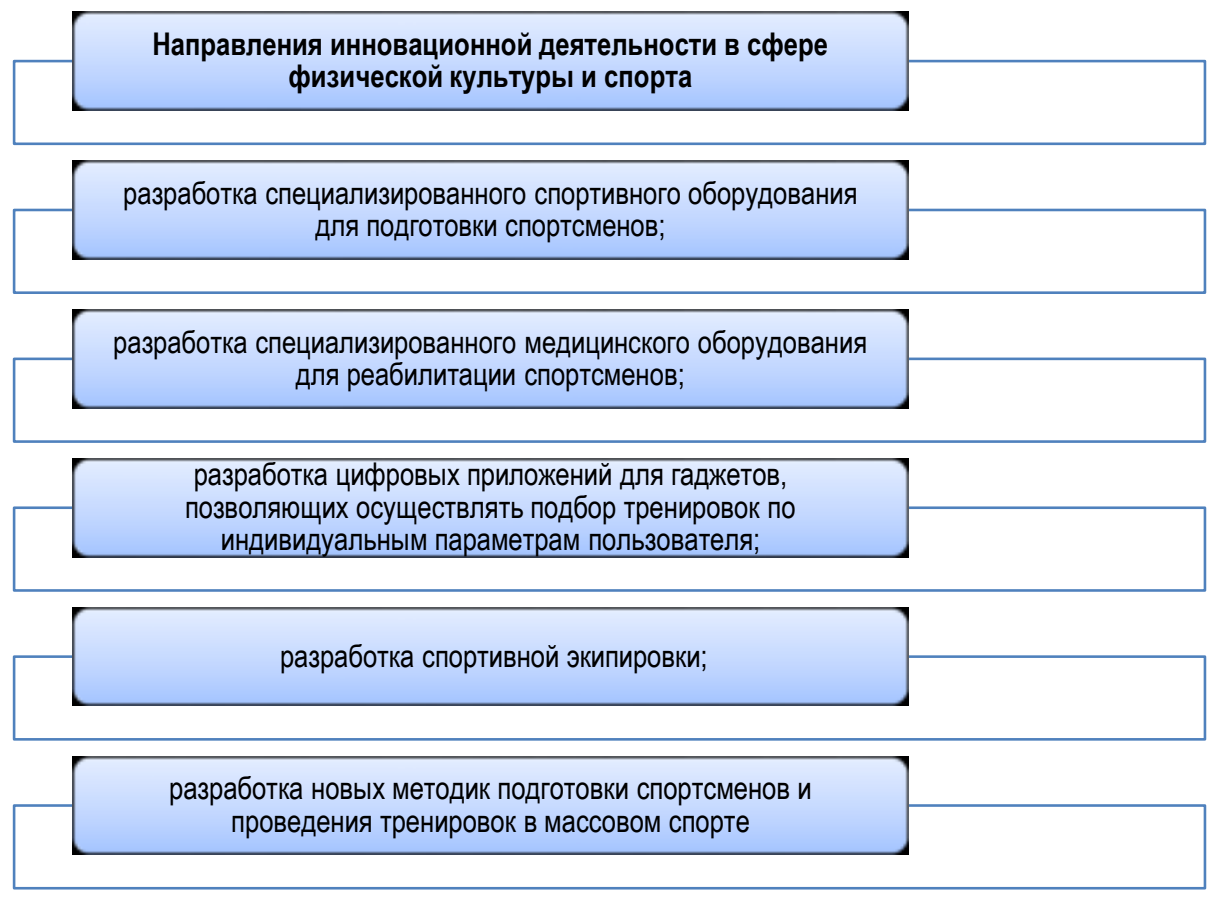

\section{Рис. 2. Направления инновационной деятельности в сфере физической культуры и спорта}

Согласно рис. 2, можно сделать вывод, что для разработки инноваций в сфере физической культуры и спорта необходимо применения знаний из различных наук и дисциплин (например, медицины), а также использование разнообразных новаторских технологий.

В настоящее время разработкой и внедрением инноваций занимаются многие компании (Nike, Adidas и др.), как в России, так и за рубежом. 
Например, при подготовке спортсменов к сочинской Олимпиаде в Российской Федерации использовался комплекс инновационных технологий и приемов, который позволил решить ряд задач перед спортсменами: дистанционная поддержка, стимулирование концентрации внимания спортсмена, оказание информационной помощи спортсменам и тренерам и пр. (рис. 3).



Рис. 3. Инновационные технологии, применяемые при подготовке спортсменов
к сочинской Олимпиаде в России

Кроме вышеназванных инновационных технологий при подготовке спортсменов используются и другие: ReconJet - интерактивные очки, которые состоят из процессора, видеокамеры, акселератора в трёх измерениях; AdidasMiCoachElite и MLS - футбольная смарт-технология, основное назначение которой - оснащение всех игроков и тренера футбольной лиги США комплектом устройств, обеспечивающих контроль за физиологическим состоянием людей во время физической активности; miCoachSmartBall - уникальный футбольный мяч, который определяет точное пересечение линии ворот в автоматическом режиме.

Рассмотренные выше примеры из практики инновационной деятельности зарубежных и российских компаний подтверждают факт активных разработок инновационных технологий в сфере физкультуры и спорта5.

Таким образом, благодаря инновациям в сфрере физической культуры и спорта людям становится интереснее, легче и доступнее заниматься спортом. А так же, возможно самое главное, добиваться высоких результатов и получать удовольствие от физического процесса.

${ }^{1}$ Анализ информационных технологий в области физической культуры и спорта / Иванова Л.А., Савельева О.В.//Научно-методический электронный журнал "Концепт". 2015. № 8. С. 81-85 
2 Указ президента РФ от 7 мая 2018 г. №204 "О национальных целях и стратегических задачах развития Российской Федерации на период до 2024 года".

${ }^{3}$ Сводный отчет по форме федерального статистического наблюдения № 1-ФК "Сведения о физической культуре и спорте" за 2018 год//Официальный сайт Министерства спорта РФ [Электронный ресурc]. URL: https://www.minsport.gov.ru (дата обращения 03.10.2019)

${ }^{4}$ Кудинова В.А. Эффективность как стратегическое направление развития физической культуры и спорта в современной России// Ученые записки университета имени П.Ф. Лесгафта. - 2018. № 9 (163).URL: http://lesgaft-notes.spb.ru/files/9-163-2018/p173-177.pdf (дата обращения 02.10.2019)

5 Официальный сайт инновационного центра Олимпийского комитета России [Электронный pecypc]. - URL: https://icroc.ru/ (дата обращения: 02.10.19).

\title{
INNOVATIONS IN THE FIELD OF PHYSICAL EDUCATION AND SPORTS
}

\author{
(C) 2019 Savelyeva Olga Viktorovna \\ Senior lecturer \\ (c) 2019 Abramova Veronika Yurievna \\ Student \\ Student of Samara state University of Economics \\ E-mail: veronka9909@mail.ru
}

Keywords: innovations, innovative activity, innovations in the field of physical education and sports.

In this article directions of the development of innovations in the field of physical education and sports, existing innovative projects in the field of physical education and sports are considered.

УДК 796

Код РИНЦ 77.00 .00

МОТИВАЦИЯ СТУДЕНТОВ ПОСЕЩАТЬ СПОРТИВНЫЕ УНИВЕРСИАДЫ

\author{
(c) 2019 Ханиева Эльвира Рамизовна \\ студент \\ (c) 2019 Налимова Марина Николаевна \\ старший преподаватель \\ Самарский государственный экономический университет \\ E-mail: elvirakhanieva23@yandex.ru
}

Ключевые слова: спортивный туризм, мотивация, туристское поведение, общение с друзьями, соперничество.

В статье рассматриваются мотивы посещения спортивных универсиад в области спортивнооздоровительного туризма. Основная цель заключается в выявлении основных параметров моти- 